Konrad KUŹMA ${ }^{1}$, Norbert GRZESIK ${ }^{1}$, Janusz ĆWIKLAK ${ }^{1}$, Mariusz ZIEJA ${ }^{2}$

${ }^{I}$ Polish Air Force University (Lotnicza Akademia Wojskowa)

${ }^{2}$ Air Force Institute of Technology (Instytut Techniczny Wojsk Lotniczych)

\title{
ANALYSIS OF A POSSIBILITY OF USING FUZZY LOGIC TO ASSESS THE RELIABILITY OF AIRCRAFT ON-BOARD SYSTEMS
}

\section{Analiza możliwości zastosowania logiki rozmytej w ocenie niezawodności lotniczych systemów pokładowych}

\begin{abstract}
The paper attempts to present the current state of knowledge in the use of fuzzy logic in order to assess the reliability of technical objects over the past two decades. In world literature, one can recall three main trends related to the use of fuzzy logic in the reliability estimation. The first one deals mainly with an analysis and assessment of the risk of failure. In the second mainstream, the researchers try to analyse the human factor, which also influences system malfunction. The third group of reliability studies the possibility of using fuzzy logic for proper service planning and thus preventing damage. In each of the three mentioned trends, fuzzy logic complements the classic methods of estimating and predicting reliability.
\end{abstract}

Keywords: reliability, fuzzy logic, aircraft on-board systems

Streszczenie: W niniejszej pracy podjęto próbę przedstawienia aktualnego stanu wiedzy $w$ zakresie wykorzystania logiki rozmytej do oceny niezawodności obiektów technicznych na przestrzeni ostatnich kilkunastu lat. W światowej literaturze można zauważyć trzy główne nurty zwiąane z wykorzystaniem logiki rozmytej w ocenie niezawodności. Pierwszy zajmuje się głównie analiza i ocena ryzyka powstawania awarii. W drugim nurcie naukowcy próbują analizować czynnik ludzki, który ma także wplyw na powstawanie awarii. Trzecia grupa badań nad niezawodnościa wskazuje na możliwość wykorzystania logiki rozmytej do odpowiedniego planowania obstug i tym samym zapobiegania powstawaniu uszkodzeń. Wkażdym z trzech wspominanych nurtów, logika rozmyta stanowi uzupetnienie dla klasycznych metod szacowania i przewidywania niezawodności.

Słowa kluczowe: niezawodność, logika rozmyta, lotnicze systemy pokładowe 


\section{Introduction}

With the development of technology, due to an increasing complexity of technical products and the desire to achieve the best possible economic effects, Man began to wonder how long these devices will continue to work without any failure. The first references to reliability date back to the 1920s, when engineers dealing with the reliability of technical objects claimed that an object will continue to operate uninterrupted as long as its weakest element operates properly. This theory, called the theory of the weakest link, was announced by Frederick Thomas Peirce in 1926 [17]. After World War II, there was a significant breakthrough in the previous way of thinking about object reliability and its weakest link. It was found that the identification of the weakest element is often problematic. Additionally, it must be assumed that each element of a technical system affects its reliability. On the basis of such considerations, at the turn of the 1940s and 1950s, a new science called the reliability theory emerged. The precursors of this theory are a German engineer Robert Lusser and a German mathematician Erich Pieruschke, who formalized their reliability theories. In 1944 the so-called Lusser's product law was announced, which assumed that the reliability of a device is significantly lower than the reliability of its individual components and is expressed by a reliability product of its individual components [18]. In the 1960s, further development of the reliability theory occurred, in relation to an increase in the complexity of systems, mainly electronic ones, which required substantial financial investments in order to keep them in a proper operational condition. An increasing number of engineers started to claim that it is better to design and produce a reliable device rather than wait for its failure or spend huge sums of money on its possible upgrading. Newer and better methods of estimating reliability were looked for.

The reliability theory is based on two areas of mathematics: probability and statistics [3]. In accordance with its definition, reliability is understood as an object or a system quality, which indicates whether a given object operates in a failurefree manner under certain conditions of operation during a pre-defined time. One of the measures of reliability is the likelihood of satisfying operational requirements by an object. In the probabilistic approach, reliability can be represented as:

$$
R(t)=P(T \geq t)
$$

where: $R(t)$ is the reliability of an object in a given moment of time $P(T \geq t)$ means the probability that the durability of object $\mathrm{T}$ will be greater than the assumed time $t$. 
The main drawback of a probabilistic approach in determining the reliability of complex systems is the fact that, as a rule, it does not consider all the factors affecting the failure of a technical object. The statistical data, which are taken into account in probabilistic models, only point to an existing failure and do not take into account the reasons for its occurrence [22]. The causes of failure are variable and may depend on plenty of technical factors as well as factors not related to technology, such as the quality of service, timeliness of service, etc. More and more often, we deal with an uncertain situation of occurring a failure. In such a case, an alternative solution to a probabilistic approach may be an approach using fuzzy logic [25] and the possibility theory [26] associated with it. This solution combines statistical data of an occurrence of failure with other factors that may affect its creation, which are assessed on the basis of man's experience.

\section{Research problem}

The aim of this paper is to attempt to present the current state of knowledge in the field of using fuzzy logic to assess the reliability of technical objects over the last several years.

At present, a single technical object is rarely discussed. Machines tend to be discussed as complex technical systems, whose reliability is dependent on the trouble-free operation of their components. In the available literature, it is possible to come across attempts of estimating reliability using fuzzy logic. Fuzzy logic is primarily designed to take into account the uncertainty associated with the occurrence of non-technical factors of damage. Since 2000, scientists have attempted to explore the issue of uncertainty of failure occurrence, trying to describe it mathematically, as well as designating it in an empirical way. In world literature, one may observe three mainstream trends associated with the use of fuzzy logic in assessing reliability.

The first one primarily deals with an analysis and risk assessment in the occurrence of failure. Risk in terms of engineering can be defined as a likelihood of an occurrence and its consequences [5]. Risk analysis is based on the study of a mutual relationship between likelihood and the consequences of an occurrence of a negative event. Both the probability of a failure and the consequences of its occurrence are burdened with a large degree of uncertainty and it is difficult to identify them precisely. Therefore, researchers are trying to use fuzzy logic, being adapted to approximating inaccurate information. In study [14], the authors presented the methodology of risk assessment in rupturing a cylinder of isobutane, based on the fault tree analysis diagram and event tree analysis, in which, rather 
than specific numerical values, fuzzy numbers were used for the input and output data. A comparison was made between the conventional fault tree analysis and a modified method, part of which is fuzzy logic. On the basis of a simple case study, it was proved that risk assessment using fuzzy logic designates more real values than the classic fault tree analysis and the event tree method. Similar conclusions were obtained after an introduction of a method using fuzzy logic to a quantitative risk assessment of accidents at work in two Italian industrial works [16]. This method was checked on real source data from a company producing tires and from a chemical plant. The proposed method allows assessing the level of risk to which workers are exposed in various sectors of industry and helps to designate preventive measures in order to reduce the risk of an accident at work. Attempts were made to use fuzzy logic for risk assessment in the implementation of a helicopter mission. The study [21] shows a case study of a risk assessment of a helicopter disaster, which is dependent upon the intensification of actions and the likelihood of a disaster.

In the second mainstream, experts try to analyse the human factor, which also contributes to the occurrence of a failure. Man is an indispensable element of social engineering and its possible omissions or mistakes exert a significant impact on a failure-free work of operated devices [23]. Research shows that over 50\% damage and failures that lead to equipment malfunction are caused by the human factor [11]. The factor is linked to the concept of Human Reliability Assessment (HRA), introduced in 1962 by Munger [15]. It means that a task was executed by a person in a particular state of a technical system, within pre-determined time constraints. The performed task was not burdened with any errors. An error, in this sense, is defined as a likelihood of failure in performing a task or executing a forbidden task, which may contribute to a failure situation [4]. Many factors, both personal and environmental ones, may have an impact on human reliability. Due to the uncertain nature of the above-mentioned factors, fuzzy logic is introduced into the methodology of estimating reliability. In this way, it is possible to accurately model uncertainty. The methods using fuzzy logic combine classic techniques of reliability estimation with the base of fuzzy logic deduction principles, based on expert knowledge in this field, providing analysts access to current and repeated expert rules [20]. These methods are discussed in many scientific studies and relate to different fields of technology. The study [7] presents a methodology which characterises human reliability based on the concepts of fuzzy logic sets in order to reduce the possibility of committing human error in oil refineries. Another field which is important from the point of view of human security, in which there have been attempts to use fuzzy logic is nuclear energy. In the available literature, there are methods based on fuzzy logic deduction and expert assessment in order to 
determine the likelihood of an occurrence of human error, when performing tasks by operators of nuclear plants [13]. There have also been attempts to use fuzzy logic in connection with dynamic fault tree models based on Markov chains. These studies were to assess the reliability of, e.g. level crossings in Morocco [6], or avionics systems which are critical for safety [24].

The third group of reliability research indicates the possibility of using fuzzy logic for appropriate maintenance planning and thereby preventing damage. In order to anticipate and prevent the possibility of failure, various servicing strategies are implemented, whose main task is to increase the reliability of the operated objects or whole technical systems. An optimal operating strategy is usually selected by combining the assessment of a technical condition of the analysed equipment and the assessment of the risk of failure. The most popular maintenance strategies are as follows [8]:

- Time-Based Maintenance (TBM) - maintenance dependent on time, during which overhauls and inspections are conducted in strictly defined time intervals;

- Condition Based Maintenance (CBM) - maintenance which depends on the state, in which the possibility of failure does not stem directly from the age of the device, but from the way of its production and operation;

- Reliability-centred Maintenance (RCM) - the most popular and developing strategy aimed at obtaining reliability.

RCM is a well-structured and logical decision-making process, whose primary purpose is to identify and implement actions that are necessary to maintain high reliability of objects and technical systems. The essence of the RCM approach is illustrated by seven basic questions formulated in the year 1999 by the International Society of Automotive Engineers [12]:

1. What are the functions of a technical object, and what are the corresponding performance standards (e.g., efficiency, product quality class, cost of operation, safety) in the context of current production tasks?

2. In what way may an object fail to meet its functions (how does damage arise)?

3. What could be the cause of each functional damage?

4. What could be the consequences of each damage (what happens, when does damage occur)?

5. What is the significance of each of these effects of damage?

6. What should be done to predict or prevent each damage?

7. What should be done when it is impossible to take appropriate preventive action?

By analysing the responses to these questions, it is possible to determine an appropriate maintenance strategy, at the same time ensuring their maximum 
efficiency and adaptation to the specific needs of the user [19]. Such an approach is shown in paper [9], which describes a study case of an Indonesian company producing threads. The machine parts whose failure cause a cessation of a production process were taken into consideration. The RCM diagram, using fuzzy logic, was developed containing questions for causes of symptoms and types of failures and to model imprecise responses in the RCM diagram. Other authors also proved that an approach to planning maintenance, which uses fuzzy logic is effective. The methodology was applied to plan the maintenance of tools for cold work. The authors presented a decision-making process for the planning of service operations of the discussed tools, based on fuzzy logic. The results which they obtained confirmed the assumptions that this method may be used in the planning of maintenance of tools for cold work [2]. Fuzzy logic was also successfully used to identify specific maintenance tasks for the equipment used to perform reactions in a chemical plant [1] or to choose an appropriate strategy for the maintenance of significant elements of a conventional milling machine [10].

In each of the discussed trends, fuzzy logic complements classic conventional methods of estimation and reliability prediction. It is used successfully, wherever there is a need to model uncertainties or ambiguities or to include other nontechnical factors, such as the human factor. Based on an analysis of literature data, it can be concluded that fuzzy logic may be used in methodologies of reliability assessment in various technical systems.

\section{Summary, Conclusions}

Aircraft on-board systems, as well as other technical systems, must be characterized by high reliability and efficiency in the execution of their mission. Unfortunately, very often, the factors which cause malfunctioning of a given system are random and cannot be precisely determined. Besides, a man exerts a significant role in the operation of these systems, since their errors can contribute to the emergence of adverse changes and therefore to a failure or a malfunction. Fuzzy logic gives an opportunity of better approximation of reality in modelling changes which occur in machines and equipment during their operation. Taking into account the uncertainties and ambiguities of factors which have an impact on the reliability of on-board systems as well as the results of studies available in literature data, the authors formulated a hypothesis that the theory of fuzzy logic sets gives an opportunity to build a multidimensional model of efficiency of a selected on-board system, allowing an assessment of factors affecting the formation of system malfunction. 


\section{Direction of further research}

The authors intend to develop a methodology for the assessment of the reliability of on-board systems, using fuzzy logic. The authors will deal with a selected aircraft armament system in order to assess its reliability based on classic probabilistic models of reliability. A comparison of a model, based on fuzzy logic with a probabilistic model, appears to give an unambiguous answer to the question of whether fuzzy logic may facilitate building a multidimensional reliability model of aircraft on-board systems.

\section{References}

1. Aguilar J., Cerrada M., Morillo K.: A reliability-based failure management. Application using intelligent hybrid Systems. Supervision and Safety for Technical Processes, Budapest 2000.

2. Baban M., Baban C. F., Blaga S.: Planowanie obsługi narzędzi do obróbki plastycznej na zimno z wykorzystaniem logiki rozmytej. Eksploatacja i Niezawodność, 3, 2010.

3. Barlow R.E., Proshan F.: Mathematical Theory of Reliability, Wiley, London 1965.

4. Baziuk P.A., Rivera S.S., Núñez Mc Leod J.: Fuzzy Human Reliability Analysis: Applications and Contributions, Review Advances in Fuzzy Systems, Volume 2016.

5. Biedgunis S., Smolarkiewicz M., Podwójci P., Czapczuk A.: Mapa ryzyka funkcjonowania rozległych systemów technicznych, Rocznik Ochrona Środowiska, Vol. 9, 2007.

6. Boudnaya J., Mkhida A., Sallak M.: Dependability analysis of Level Crossing Systems using a fuzzy dynamic fault tree approach. European Safety and Reliability Conference ESREL, Switzerland 2015.

7. Domech J., Tanscheit R., Vellasco M.M., Pacheco M.A., Swarcman D.M.: A Fuzzy Approach to the Study of Human Reliability in the Petroleum Industry, Theoretical Advances and Applications of Fuzzy Logic and Soft Computing, Springer Berlin Heidelberg 2007.

8. Dzierżanowski Ł., Gasz R.: Implementacja modelu Reliability-Centered Maintenance do komputerowego wspomagania podejmowania decyzji. In: Komputerowo zintegrowane zarządzanie. T.I. Opole: Oficyna Wydawnicza Polskiego Towarzystwa Zarządzania Produkcją, 2011.

9. Felecia: Fuzzy Logic Reliability Centered Maintenance. Jurnal Teknik Industri, 16(2), 2014, DOI: 10.9744/jti.16.2.121-126.

10. Gupta G., Mishra R.: A Failure Mode Effect and Criticality Analysis of Conventional Milling Machine Using Fuzzy Logic. Quality and Reliability Engineering International, 33, 2016. 
11. Laskowski D.: Prognozowanie niezawodności złożonych obiektów technicznych, Biuletyn WAT, vol. LV, numer specjalny, 2006.

12. Legutko S.: Trendy rozwoju utrzymania ruchu urządzeń i maszyn, Eksploatacja i Niezawodność, 2, 2009.

13. Li P.-C., Chen G.-H., Dai L.-C., Li Z.: Fuzzy logic-based approach for identifying the risk importance of human error. Safety Science, 48, 2010.

14. Markowski A.S., Mannan M.S., Bigoszewska A.: Fuzzy logic for process safety analysis, Journal of Loss Prevention in the Process Industries, Vol. 22, Iss. 6, 2009.

15. Munger S., Smithy R., Payne D.: An index of electronic equipment operability, data store, Tech. Rep. AIR-C43-1/62-RP, American Institutes for Research, Pittsburgh, USA, 1962.

16. Muré S., Demichela M.: Fuzzy Application Procedure (FAP) for the risk assessment of occupational accidents, Journal of Loss Prevention in the Process Industries, Vol. 22, Iss. 5, 2009.

17. Peirce F.T.: Tensile Tests for Cotton Yarns V. - "The Weakest Link" Theorems on the Strength of Long and of Composite Specimens. J. Text. Inst. (Trans.), 17, 1926.

18. Pieruschka E.: Principles of reliability. Englewood Cliffs, N.J.: Prentice-Hall, 1963.

19. Pietrzyk A., Uhl. T.: Optymalizacja konstrukcji systemów diagnostycznych z zastosowaniem algorytmów genetycznych. Diagnostyka, Vol. 30, t. II, 2004.

20. Podofillini L., Dang V.N., Zio E., Baraldi P, Librizzi M.: Using Expert Models in Human Reliability Analysis - A Dependence Assessment Method Based on Fuzzy Logic. Risk analysis: an official publication of the Society for Risk Analysis, 30, 2010.

21. Pokorádi L.: Application of fuzzy set theory for risk assessment, Journal of Konbin, $2,3(14,15), 2010$.

22. Rotshtein A., Katielnikov D., Pustylnik L.: Reliability Modeling and Optimization Using Fuzzy Logic and Chaos Theory, International Journal of Quality, Statistics, and Reliability, Vol. 2012, Article ID 847416, 2012.

23. Szopa T.: Niezawodność i bezpieczeństwo. Oficyna Wydawnicza Politechniki Warszawskiej, Warszawa 2009.

24. Tu J., Cheng R., Tao Q.: Reliability Analysis Method of safety-critical avionics system based on Dynamic Fault Tree under Fuzzy uncertainty. Eksploatacja i Niezawodność - Maintenance and Reliability, 17 (1), 2015.

25. Zadeh L.A.: Fuzzy sets in Information and Control, s. 338-353, vol. 8, 1965.

26. Zadeh L.A.: The concept of linguistic variable and its applications to approximate reasoning, Part 1-3, Information Sciences, 1975. 


\section{ANALIZA MOŻLIWOŚCI ZASTOSOWANIA LOGIKI ROZMYTEJ W OCENIE NIEZAWODNOŚCI LOTNICZYCH SYSTEMÓW POKLADOWYCH}

\section{Wprowadzenie}

Wraz z rozwojem techniki, ze względu na coraz to większą złożoność wyrobów technicznych oraz chęć osiagnięcia jak najlepszych efektów ekonomicznych, człowiek zaczął się zastanawiać, jak długo urządzenia te będą w stanie pracować bezawaryjnie. Pierwsze wzmianki o niezawodności sięgają lat 20. ubiegłego wieku, kiedy to inżynierowie zajmujący się niezawodnością obiektów technicznych stwierdzili, że obiekt będzie tak długo pracował bezawaryjnie, dopóki będzie prawidłowo działał jego najsłabszy element. Teorię tę, nazwaną teorią najsłabszego ogniwa, ogłosił w 1926 r. Frederick Thomas Peirce [17]. Po II wojnie światowej nastąpił znaczący przełom w dotychczasowym myśleniu o niezawodności obiektu i jego najsłabszym ogniwie. Stwierdzono, że wskazanie najsłabszego elementu jest często problematyczne, a dodatkowo należy przyjmować, że każdy element systemu technicznego ma wpływ na jego niezawodność. Na bazie takich rozważań powstała na przełomie lat 40. i 50 . ubiegłego wieku nauka zwana teorią niezawodności. Za prekursorów tej teorii uznaje się niemieckiego inżyniera Roberta Lussera oraz niemieckiego matematyka Ericha Pieruschkę, którzy sformalizowali swoje teorie niezawodności. W 1944 r. zostało ogłoszone tzw. prawo Lussera, które zakładało, że niezawodność urządzenia jest znacznie niższa od niezawodności poszczególnych jego elementów i wyraża się iloczynem niezawodności poszczególnych elementów składowych [18]. W latach 60. nastąpił dalszy rozwój teorii niezawodności związany ze wzrostem złożoności układów, głównie elektronicznych, które wymagały dużych nakładów finansowych na utrzymanie ich w należytym stanie eksploatacyjnym. Coraz więcej inżynierów zaczęło mieć przekonanie, że lepiej jest zaprojektować i wyprodukować niezawodne urządzenie, niż czekać na wystąpienie uszkodzenia i wydawać ogromne pieniądze na jego ewentualne usprawnienie. Zaczęto więc szukać nowych metod szacowania niezawodności. 
Teoria niezawodności opiera się na dwóch dziedzinach matematyki: rachunku prawdopodobieństwa i statystyce [3]. Zgodnie z definicją ,niezawodność" rozumiana jest jako własność obiektu lub systemu mówiąca o tym, czy dany obiekt pracuje bezawaryjnie $\mathrm{w}$ określonych warunkach eksploatacji przez $\mathrm{z}$ góry określony czas. Jedną z miar niezawodności jest prawdopodobieństwo spełnienia przez obiekt stawianych przed nim wymagań eksploatacyjnych. W ujęciu probabilistycznym niezawodność można przedstawić jako:

$$
R(t)=P(T \geq t)
$$

gdzie: $R(t)$ oznacza niezawodność obiektu w danej chwili czasu

$P(T \geq t)$ oznacza prawdopodobieństwo, że trwałość obiektu $T$ będzie większa od założonego czasu $t$.

Głównym mankamentem podejścia probabilistycznego w wyznaczaniu niezawodności systemów złożonych jest fakt, że nie uwzględnia on z reguły wszystkich czynników mających wpływ na powstanie uszkodzenia obiektu technicznego. Dane statystyczne, które są brane pod uwage w modelach probabilistycznych, wskazują jedynie fakt wystapienia awarii, nie uwzględniając przyczyn jej wystąpienia [22]. Przyczyny powstania awarii są zmienne i mogą zależeć od bardzo wielu czynników technicznych, jak również od czynników niezwiązanych z techniką, do których należą m.in. jakość i terminowość obsług itp. Coraz częściej mamy zatem do czynienia z niepewnością wystąpienia awarii. Alternatywnym rozwiązaniem dla podejścia probabilistycznego w takim przypadku może być podejście wykorzystujące logikę rozmytą [25] i powiązaną z nią teorię możliwości [26]. Takie rozwiązanie łączy ze sobą dane statystyczne wystąpienia awarii z innymi czynnikami mogącymi mieć wpływ na jej powstanie, które oceniane są na podstawie doświadczenia człowieka.

\section{Problem badawczy}

W niniejszej pracy podjęto próbę przedstawienia aktualnego stanu wiedzy w zakresie wykorzystania logiki rozmytej do oceny niezawodności obiektów technicznych na przestrzeni ostatnich kilkunastu lat.

Obecnie rzadko mówi się o pojedynczym obiekcie technicznym, raczej rozpatruje się maszyny, urządzenia jako złożone systemy techniczne, których niezawodność jest zależna od bezawaryjnego działania ich poszczególnych podzespołów. $\mathrm{W}$ wielu pracach $\mathrm{z}$ literatury przedmiotu podejmowane są próby szacowania niezawodności z wykorzystaniem logiki rozmytej. Logika rozmyta ma 
głównie za zadanie uwzględnić niepewność związaną z występowaniem innych niż techniczne czynników powstawania uszkodzeń. Począwszy od 2000 r. naukowcy próbują zgłębić zagadnienie niepewności wystapienia awarii i starają się je jak najlepiej opisać matematycznie, jak również wyznaczyć je w sposób empiryczny. W światowej literaturze można zauważyć trzy główne nurty związane z wykorzystaniem logiki rozmytej w ocenie niezawodności.

Pierwszy zajmuje się głównie analizą i oceną ryzyka powstawania awarii. Ryzyko w ujęciu inżynierskim można określić jako prawdopodobieństwo wystąpienia danego zdarzenia wraz z jego skutkami [5]. Analiza ryzyka opiera się na badaniu wzajemnego powiązania prawdopodobieństwa i skutków wystąpienia negatywnego zdarzenia. Zarówno prawdopodobieństwo wystąpienia awarii, jak też skutki jej powstania, są obarczone dużą dozą niepewności i ciężko jest je precyzyjnie określić. Dlatego też naukowcy próbują wykorzystać, przystosowaną do przybliżania nieprecyzyjnych informacji, logikę rozmytą. W pracy [14] autorzy zaprezentowali metodologię analizy ryzyka rozerwania butli izobutanu, opartą na metodzie drzewa błędów i drzewa zdarzeń, gdzie jako dane wejściowe i wynikowe, zamiast konkretnych wartości liczbowych, zastosowano liczby rozmyte. Dokonano porównania klasycznej metody drzewa błędów z metodą zmodyfikowana, której część stanowi logika rozmyta. Na bazie prostego studium przypadku wykazano, że szacowanie ryzyka wykorzystujące logikę rozmytą wyznacza bardziej realne wartości niż klasyczna metoda drzewa błędów i zdarzeń. Podobne wnioski wyciagnnięto po wprowadzeniu metody wykorzystującej logikę rozmytą do ilościowej oceny ryzyka powstania wypadków przy pracy w dwóch włoskich zakładach przemysłowych [16]. Metoda ta została sprawdzona na rzeczywistych danych źródłowych pochodzących z firmy produkującej opony oraz z zakładu chemicznego. Proponowana metoda pozwala ocenić poziom ryzyka, na które narażeni są pracownicy $\mathrm{w}$ różnych sektorach przemysłu oraz pomaga wyznaczyć procedury zapobiegawcze w celu zmniejszenia ryzyka wystąpienia wypadku przy pracy. Podjęto także próby wykorzystania logiki rozmytej do oceny ryzyka wykonania misji śmigłowców. W pracy [21] przedstawiono studium przypadku oceny ryzyka wystąpienia katastrofy śmigłowca, które uzależnione jest od nasilenia działań oraz prawdopodobieństwa katastrofy.

W drugim nurcie naukowcy próbują analizować czynnik ludzki, który ma także wpływ na powstawanie awarii. Człowiek jest nieodzownym elementem systemów socjotechnicznych, a jego ewentualne niedopatrzenia czy błędy mają znaczny wpływ na niezawodną pracę obsługiwanych urządzeń [23]. Badania dowodzą, że ponad 50\% uszkodzeń i awarii, które prowadzą do niesprawności sprzętu, leży po stronie czynnika ludzkiego [11]. Z czynnikiem tym wiąże się 
pojęcie ludzkiej niezawodności human reliability assessment (HRA), wprowadzone w 1962 r. przez Mungera [15]. Oznacza ono, że zadanie zostało wykonane przez osobę $\mathrm{w}$ określonym stanie systemu technicznego, $\mathrm{w}$ nakreślonych $\mathrm{z}$ góry ramach czasowych. Wykonane zadanie nie było przy tym obarczone żadnymi błędami. Błąd $w$ tym znaczeniu określany jest jako prawdopodobieństwo niepowodzenia wykonania zadania lub wykonania zadania zabronionego, które może przyczynić się do powstania awarii [4]. Na niezawodność człowieka wpływ może mieć wiele czynników zarówno osobowych, jak również środowiskowych. Ze względu na niepewny charakter występowania wspomnianych czynników wprowadza się do metodologii szacowania niezawodności logikę rozmytą, dzięki której można $\mathrm{w}$ dosyć precyzyjny sposób zamodelować niepewność. Metody wykorzystujące logikę rozmytą łączą klasyczne techniki szacowania niezawodności człowieka z bazą reguł wnioskowania rozmytego, opartą na wiedzy ekspertów w tej dziedzinie, dzięki czemu analitycy mają dostęp do aktualnych i powtarzalnych reguł eksperckich [20]. Metody te omawiane są w wielu pracach naukowych i dotyczą różnych dziedzin techniki. W pracy [7] przedstawiono metodologię charakteryzującą ludzką niezawodność w oparciu o koncepcje zbiorów rozmytych, mającą na celu ograniczenie możliwości popełniania błędów ludzkich w rafineriach ropy naftowej. Inną dziedziną, ważną z punktu widzenia bezpieczeństwa ludzkości, w której podjęto próby wykorzystania logiki rozmytej, jest energetyka jądrowa. W literaturze przedstawiono metody oparte na wnioskowaniu rozmytym i ocenie eksperckiej w celu określenia prawdopodobieństwa wystapienia błędu ludzkiego podczas wykonywania zadań przez operatorów elektrowni jądrowych [13]. Podejmowano także próby zastosowania logiki rozmytej w połączeniu z opartymi na łańcuchach Markowa modelami dynamicznych drzew błędów. Badania te miały na celu ocenę niezawodności np.: przejazdów kolejowych w Maroku [6] czy krytycznych dla bezpieczeństwa systemów elektroniki lotniczej [24].

Trzecia grupa badań nad niezawodnością wskazuje na możliwość wykorzystania logiki rozmytej do odpowiedniego planowania obsług i tym samym zapobiegania powstawaniu uszkodzeń. Aby przewidywać i zapobiegać możliwości wystapienia awarii, wdrażane są różnego rodzaju strategie obsługi, których głównym zadaniem jest zwiększenie niezawodności eksploatowanych obiektów czy też całych systemów technicznych. Optymalną strategię obsługi wybiera się z reguły dzięki połączeniu oceny stanu technicznego analizowanego sprzętu oraz oceny ryzyka wystąpienia awarii. Do najpopularniejszych strategii obsługi należą [8]:

- Time Based Maintenance (TBM) - obsługa zależna od czasu, gdzie wykonywanie remontów i inspekcji odbywa się w ściśle określonych odstępach czasowych; 
- Condition Based Maintenance (CBM) - obsługa zależna od stanu, gdzie możliwość wystapienia awarii nie wynika bezpośrednio z wieku urządzenia, ale także ze sposobu jego produkcji i eksploatacji;

- Reliability-Centered Maintenance (RCM) - najbardziej popularna i rozwijająca się strategia skierowana na uzyskanie niezawodności.

RCM to dobrze zorganizowany, logiczny proces decyzyjny, którego głównym celem jest zidentyfikowanie i realizacja działań niezbędnych do utrzymania wysokiej niezawodności obiektów i systemów technicznych. Istotę podejścia RCM ilustruje siedem podstawowych pytań sformułowanych w 1999 r. przez International Society of Automotive Engineers [12]:

1. Jakie funkcje spełnia obiekt techniczny i jakie odpowiadają im standardy osiagów (np. wydajności, klasy jakości produktu, kosztu eksploatacji, bezpieczeństwa) w kontekście bieżących zadań produkcyjnych?

2. W jaki sposób obiekt może zawieść w spełnianiu funkcji (w jaki sposób powstają uszkodzenia)?

3. Co może być przyczyną każdego z uszkodzeń funkcjonalnych?

4. Jakie mogą być skutki każdego z tych uszkodzeń (co się dzieje, kiedy występuje uszkodzenie)?

5. Jakie znaczenie ma każdy ze skutków tych uszkodzeń?

6. Co można zrobić, aby przewidzieć lub zapobiec każdemu z uszkodzeń?

7. Co powinno być zrobione, gdy nie można znaleźć odpowiedniego działania zapobiegawczego?

Analizując uzyskane na powyższe pytania odpowiedzi, można określić odpowiednią strategię konserwacyjną i obsługową, zapewniając jednocześnie ich maksymalną efektywność i dostosowanie do specyficznych potrzeb użytkownika [19]. Takie podejście pokazano $\mathrm{w}$ pracy [9], gdzie przedstawiono studium przypadku indonezyjskiej firmy produkującej nici. Pod uwagę brano takie części maszyn, których awaria powoduje przerwanie produkcji. Opracowano diagram RCM z pytaniami dotyczącymi przyczyn, symptomów i typów awarii, a do zamodelowania nieprecyzyjnych odpowiedzi w diagramie RCM użyto logiki rozmytej. Również inni autorzy dowiedli skuteczności podejścia do planowania obsług, które wykorzystuje logikę rozmytą. Metodologię tą zastosowano do zaplanowania obsługi narzędzi do obróbki plastycznej na zimno. Autorzy przedstawili oparty na logice rozmytej proces decyzyjny w zakresie planowania czynności obsługowych omawianych narzędzi. Uzyskane wyniki potwierdziły przypuszczenia, że metoda ta może być stosowana w planowaniu obsługi narzędzi do obróbki plastycznej na zimno [2]. Logikę rozmytą wykorzystano również z powodzeniem do określenia konkretnych zadań konserwacyjnych dla urządzeń wykorzystywanych do przeprowadzania reakcji w zakładach chemicznych [1] czy 
do wyboru odpowiedniej strategii konserwacji dla ważnych elementów frezarki konwencjonalnej [10].

W każdym $\mathrm{z}$ trzech wspominanych nurtów logika rozmyta stanowi uzupełnienie dla klasycznych metod szacowania i przewidywania niezawodności. Stosowana jest $\mathrm{z}$ powodzeniem, wszędzie tam, gdzie istnieje konieczność zamodelowania niepewności czy niejednoznaczności lub uwzględnienia innych czynników nietechnicznych, takich jak czynnik ludzki. Na podstawie analizy danych literaturowych można wysnuć wniosek, że logika rozmyta może być stosowana w metodykach oceny niezawodności różnych systemów technicznych.

\section{Podsumowanie i wnioski}

Od lotniczych systemów pokładowych, jak od każdego innego systemu technicznego, wymaga się, aby cechowały go wysoka niezawodność i skuteczność podczas wykonywania misji. Niestety bardzo często czynniki powodujące niesprawność danego systemu mają charakter losowy i nie można ich w sposób precyzyjny określić. Dodatkowo w obsłudze tych systemów znaczną rolę odgrywa człowiek, którego błędy mogą przyczyniać się do powstawania zmian destrukcyjnych, a tym samym do awarii czy niesprawności. Logika rozmyta daje możliwość lepszego przybliżenia rzeczywistości $\mathrm{w}$ modelowaniu zmian zachodzących w maszynach i urządzeniach podczas ich eksploatacji. Biorąc pod uwage niepewność i niejednoznaczność czynników mających wpływ na niezawodność lotniczych systemów pokładowych oraz wyniki badań pochodzące $\mathrm{z}$ danych literaturowych, postawiono hipotezę, że teoria zbiorów rozmytych daje możliwość budowy wielowymiarowego modelu sprawności wybranego lotniczego systemu pokładowego oraz pozwala na ocenę czynników mających wpływ na powstawanie niesprawności systemu.

\section{Kierunek dalszych badań}

Autorzy podejmą próbę opracowania metodyki oceny niezawodności lotniczych systemów pokładowych z wykorzystaniem logiki rozmytej. Jako przykład do badań zostanie przyjęty system uzbrojenia lotniczego wybranego statku powietrznego, dla którego zostanie oszacowana niezawodność na podstawie klasycznych modeli probabilistycznych niezawodności. Porównanie modelu opartego na logice rozmytej $\mathrm{z}$ modelem probabilistycznym $\mathrm{w}$ ocenie autorów da jednoznaczną odpowiedź na 
pytanie, czy za pomocą logiki rozmytej można zbudować wielowymiarowy model sprawności lotniczych systemów pokładowych.

\section{Literatura}

1. Aguilar J., Cerrada M., Morillo K.: A reliability-based failure management. Application using intelligent hybrid Systems. Supervision and Safety for Technical Processes. Budapest 2000.

2. Baban M., Baban C. F., Blaga S.: Planowanie obsługi narzędzi do obróbki plastycznej na zimno z wykorzystaniem logiki rozmytej. Eksploatacja i Niezawodność, 3, 2010.

3. Barlow R.E., Proshan F.: Mathematical Theory of Reliability, Wiley, London 1965.

4. Baziuk P.A., Rivera S.S., Núñez Mc Leod J.: Fuzzy Human Reliability Analysis: Applications and Contributions, Review Advances in Fuzzy Systems, Volume 2016.

5. Biedgunis S., Smolarkiewicz M., Podwójci P., Czapczuk A.: Mapa ryzyka funkcjonowania rozległych systemów technicznych, Rocznik Ochrona Środowiska, Vol. 9, 2007.

6. Boudnaya J., Mkhida A., Sallak M.: Dependability analysis of Level Crossing Systems using a fuzzy dynamic fault tree approach. European Safety and Reliability Conference ESREL, Switzerland 2015.

7. Domech J., Tanscheit, R., Vellasco, M.M., Pacheco, M.A., Swarcman, D.M.: A Fuzzy Approach to the Study of Human Reliability in the Petroleum Industry, Theoretical Advances and Applications of Fuzzy Logic and Soft Computing, Springer Berlin Heidelberg 2007.

8. Dzierżanowski Ł., Gasz R.: Implementacja modelu Reliability-Centered Maintenance do komputerowego wspomagania podejmowania decyzji. W: Komputerowo zintegrowane zarządzanie. T.I. Opole: Oficyna Wydawnicza Polskiego Towarzystwa Zarządzania Produkcją, 2011.

9. Felecia: Fuzzy Logic Reliability Centered Maintenance. Jurnal Teknik Industri, 16(2), 2014, DOI: 10.9744/jti.16.2.121-126.

10. Gupta G., Mishra R.: A Failure Mode Effect and Criticality Analysis of Conventional Milling Machine Using Fuzzy Logic. Quality and Reliability Engineering International, 33, 2016.

11. Laskowski D.: Prognozowanie niezawodności złożonych obiektów technicznych, Biuletyn WAT, vol. LV, numer specjalny, 2006.

12. Legutko S.: Trendy rozwoju utrzymania ruchu urządzeń i maszyn, Eksploatacja i Niezawodność, 2, 2009.

13. Li P.-C., Chen G.-H., Dai L.-C., Li Z.: Fuzzy logic-based approach for identifying the risk importance of human error. Safety Science, 48, 2010.

14. Markowski A.S., Mannan M.S., Bigoszewska A.: Fuzzy logic for process safety analysis, Journal of Loss Prevention in the Process Industries, Vol. 22, Iss. 6, 2009. 
15. Munger S., Smithy R., Payne D.: An index of electronic equipment operability, data store, Tech. Rep. AIR-C43-1/62-RP, American Institutes for Research, Pittsburgh, USA, 1962.

16. Muré S., Demichela M.: Fuzzy Application Procedure (FAP) for the risk assessment of occupational accidents. Journal of Loss Prevention in the Process Industries, Vol. 22, Iss. 5, 2009.

17. Peirce F.T.: Tensile Tests for Cotton Yarns V. - "The Weakest Link" Theorems on the Strength of Long and of Composite Specimens. J. Text. Inst. (Trans.), 17, 1926.

18. Pieruschka E.: Principles of reliability. Englewood Cliffs, N.J.: Prentice-Hall, 1963.

19. Pietrzyk A., Uhl T.: Optymalizacja konstrukcji systemów diagnostycznych z zastosowaniem algorytmów genetycznych. Diagnostyka, Vol. 30, t. II / 2004.

20. Podofillini L., Dang V.N., Zio E., Baraldi P., Librizzi M.: Using Expert Models in Human Reliability Analysis - A Dependence Assessment Method Based on Fuzzy Logic. Risk analysis: an official publication of the Society for Risk Analysis, 30, 2010.

21. Pokorádi L.: Application of fuzzy set theory for risk assessment. Journal of Konbin, 2,3 (14,15), 2010.

22. Rotshtein A., Katielnikov D., Pustylnik L.: Reliability Modeling and Optimization Using Fuzzy Logic and Chaos Theory. International Journal of Quality, Statistics, and Reliability, Vol. 2012, Article ID 847416, 2012.

23. Szopa T.: Niezawodność i bezpieczeństwo. Oficyna Wydawnicza Politechniki Warszawskiej, Warszawa 2009.

24. Tu J., Cheng R., Tao Q.: Reliability Analysis Method of safety-critical avionics system based on Dynamic Fault Tree under Fuzzy uncertainty. Eksploatacja i Niezawodność - Maintenance and Reliability, 17 (1), 2015.

25. Zadeh L.A.: Fuzzy sets in Information and Control, s. 338-353, vol. 8, 1965.

26. Zadeh L.A.: The concept of linguistic variable and its applications to approximate reasoning, Part 1-3, Information Sciences, 1975. 